\title{
Walking a mile in their shoes Librarians as teaching faculty
}

$\mathrm{I}^{\mathrm{r}}$ we were to tell you that all of the professional librarians at Arcadia University in Glenside, Pennsylvania, teach information literacy sessions, you would not find this news very surprising. After all, this is a common situation at many academic institutions with well-developed information literacy programs.

However, what if we were to say that all of us teach, or have taught in the recent past, a semester-long academic course not dedicated to information literacy? This is a much more unique situation, and it has changed our perceptions of faculty. We have also seen our teaching experience change how faculty members view librarians, and it has helped enhance the perception of librarians as educators throughout the campus community.

By reflecting on our collective experience, we have been able to identify several positive outcomes that we hope will encourage other librarians to explore the potential benefits inherent in teaching as an adjunct professor. To this end, this article incorporates personal reflections from Arcadia's librarians, including the library director, in order to illustrate important insights.

At Arcadia University, librarians have taken several paths towards teaching semester-long courses. One librarian teaches a technology course as an adjunct professor in the university's School Library Certification program. Another librarian is collaborating with our International Peace and Conflict Resolution program to teach a two-credit Russian Language course designed to support graduate students during a class trip overseas. However, most of our other teaching opportunities have developed as a result of a relatively new, and largely interdisciplinary, undergraduate curriculum, which was established at Arcadia in 2008.

Two components of that curriculum in particular, First Year Seminars and University Seminars, are ideal places for librarians to teach, because these courses are not tied to a specific discipline. In fact, by design, the First Year and University Seminars provide an opportunity for faculty to develop entirely new courses from scratch that allow them to explore interests in subjects they don't ordinarily teach, or that fall outside of their usual departmental focus.

It is worth noting that librarians at Arcadia have faculty status, but that this status is ambiguous at best, and has been described in the past as only "for the purposes of governance." With the implementation of the new curriculum, librarians saw an opportunity to increase their visibility and reinforce their role as "faculty" members who are fully engaged in the teaching and learning process.

Within the new undergraduate curriculum, librarians at Arcadia have chosen to teach courses by themselves, co-teach with other librarians, and in several instances to co-teach with full-time academic faculty members as their partners. The topics of courses taught

\footnotetext{
Adam Balcziunas was the serials librarian at Arcadia University at the time of writing. He is currently electronic resources and systems librarian at King's College in Wilkes-Barre, Pennsylvania, e-mail: adam.balcziunas@ gmail.com, and Larissa Gordon is information literacy coordinator and reference librarian at Arcadia University, e-mail: gordonl@arcadia.edu

๑ 2012 Adam Balcziunas and Larissa Gordon
} 
have also varied widely. Some topics are tangentially related to the work of a librarian, such as a course on copyright and another on censorship. Likewise, the library director, who also oversees instructional technology at Arcadia and has an Ed.D. in instructional technology, teaches a course on "digital natives" that falls within her areas of expertise. However, other course topics fall much further afield, incorporating our individual interests and passions into the subject matter, such as a class on science fiction and another about the impact of media on social movements.

\section{Connection with campus faculty}

As other librarians have noted, one of the joys of the semester-long teaching experience is the opportunity to form a richer and deeper connection with students than is usually possible during a typical reference desk interaction or information literacy workshop session. ${ }^{1}$ While this is certainly true for all the librarians at Arcadia, the most surprising and potentially useful realization we have gained from our experience has been a better understanding of the work that faculty are engaged in, and perhaps a measure of insight into why they occasionally react negatively to or, more often, simply do not acknowledge librarians' information literacy overtures.

First, the difficulty of planning and delivering course content, taking into account all of the various requirements of the seminar format, has been a bigger challenge than many of us expected. The following is an excerpt from an interview with one exasperated librarian:

I did not know how long it would take to cover content in class. Many housekeeping items took way longer than I thought. Having to repeat things over and over again took up time too. I had to figure out how to guide students to do some basic tasks (where to go on Blackboard, etc.). All of this is not related to class content. I understand now how hard it is to schedule extra things into the class-such as an information literacy session-particularly without a

long lead time.

Teaching has given us greater empathy for faculty because we experience firsthand the same challenges they face when they teach. As a result, we realize that sometimes we might expect too much as librarians when we attempt to collaborate with them on information literacy initiatives.

One librarian commented succinctly: "Now I know why faculty are so protective of their time!"

In fact, several librarians have found that they do not give full attention to information literacy in their own courses because it is hard for them to squeeze in the session, or to remember to focus on information literacy concepts amid all of the other content specific topics which need to be covered in their courses.

Realizing that he did not design information literacy instruction very well in his own class prompted one librarian to remark, "It makes me think a bit more about how I as a librarian can help faculty teach their students, but structure my requests so that I don't make more work for the faculty member." Thus, it is often best to work as closely as possible with the faculty member's original syllabus and assignment structure, and to suggest larger changes, such as extra assignments or library workshop sessions, in a way that will encourage faculty to incorporate these ideas into their syllabi next time they teach, rather than asking them to do so after their syllabus has been finalized for the semester.

On a similar note, we have also gained a better understanding of why instructors often wait to contact us about instruction until late in the semester, even at times when it might make sense for the librarian to come into the classroom earlier. Teaching over a span of several months has given us insight into how long it can take for students to form a relationship with the instructor and with each other. The classroom dynamic develops gradually and the personality of a particular class may not emerge until the second half of the semester. Therefore, aside from the reason that 
most large research papers usually are not assigned until late, it may be most effective to schedule information literacy instruction sessions later in the semester because the librarians will be able to take advantage of a more well-developed classroom dynamic, and students who are likely to be more comfortable with the class, will be more engaged, and more willing to participate.

Those of us who do not co-teach also have learned how isolated one could feel during the process. One librarian provided the following perspective:

Teaching is often very lonely if you do not do it with a partner. Having someone to talk to can be wonderful, which is why I've tried to encourage the faculty I chat with about library sessions to feel free to discuss other issues as well.

This insight explains why so many faculty-particularly new faculty members or new teachers-start talking to us unprompted about their class in ways that are not related to information literacy when we are conferencing with them. Our experiences teaching full-semester courses have allowed us to become more active participants in these discussions, because we have shared experiences to draw upon in our conversations with faculty.

\section{Faculty perception of librarians}

More than one librarian has also reported that teaching a semester-long course has elevated their opinion about their own status and that faculty in turn also seem to treat them more as peers. One librarian noted,

When I taught, conversations with faculty were different. We spoke more like colleagues. We could talk about different types of students, challenges we faced teaching, share resources, etc.; I am engaged in the same process as faculty.

Studies, such as the Ithaka S+R Library
Survey, have shown that "faculty respondents place strong value in the traditional functions of the library as an institution that collects and maintains collections for research," while librarians focus more on the services they provide, and their role as teachers and educators. ${ }^{2}$ Being able to speak the same language as faculty members has, we believe, helped faculty to learn to see us more as true educators on campus. This increased connection with faculty members also likely came about because librarians are attending more professional development training sessions, teaching and learning discussions, and curriculum information sessions on campus. Along with our faculty peers, we seek to learn more about the teaching and learning process to support not only our information literacy work but our work as adjunct instructors.

\section{Challenges}

Despite the many benefits and rewards of teaching full-semester courses, the opportunities have not come without challenges. The increased workload, and the scheduling difficulties that accompany it are the main challenge cited by all librarians. Teaching semester long courses technically falls outside the regular job duties of each librarian, and so we are contracted as adjunct instructors. Therefore, while we receive an additional paycheck, our time spent in class and preparing for class needs to be added to our regular hours working as full-time librarians.

The result is that all the librarians have to work late nights or early mornings in order to make up hours. Scheduling also has become an issue. The fact that we all teach at different times, combined with our library outreach and library instruction responsibilities, make it more difficult to schedule routine meetings and reference desk hours. In the end, it was decided that librarians can only teach during the last session of the day, or during evening hours.

Another challenge mentioned by the librarians is adapting to the different type of planning required to teach a course over 
an extended period of time. One librarian explained,

I had never had to come up with a plan for teaching anything longer than a workshop. It was a real challenge to figure out how to sequence and arrange the readings, discussions, and assignments so that they built on each other over the course of the semester.

One strategy for addressing this challenge is to co-teach with another faculty member. Co-teaching allows the librarian to learn from an experienced faculty member and share responsibility for the course, while also facilitating a closer working relationship with faculty. According to one librarian,

Co-teaching with a faculty member offered me the opportunity to learn from someone more experienced than I was, over a longer period of time, and in more depth than simply observing another librarian's information literacy session.

When this collaboration works, there is no better form of outreach, as the instructors we co-teach with become our biggest champions.

\section{Concluding thoughts}

The librarians' teaching efforts have seemed like very logical extensions of their liaison roles, fostering a greater immersion in the academic life of the university, and increasing collaborative activity with faculty across campus. The library director continues to encourage the librarians to teach because it "helps us to better understand faculty and gives us a broader perspective of the faculty job." This understanding has permitted us to become active and engaged members of the campus community and to work more strategically with faculty members as we seek to more fully integrate information literacy into the curriculum.

We would like to thank Jeanne Buckley, Karen Kohn, Michelle Reale, and Calvin Wang for sharing their thoughts with us and making this reflection possible.

\section{Notes}

1. Jane Kemp, "Isn't Being a Librarian Enough? Librarians As Classroom Teachers," College and Undergraduate Libraries 13(3) (2006): 3-23; Kathy Campbell, "When a Librarian Enters the Classroom: My Experiences Teaching a Freshman Experience Class," CERL News, 69 (2008): 598-601.

2. Matthew P. Long and Roger C. Schonfeld, "Ihaka S+R Library Survey 2010: Insights from U.S. Academic Library Directors," accessed April 29, 2012, www.ithaka.org/ithakas-r/research/ithaka-s-r-library-survey-2010/ insights-from-us-academic-library-directors. pdf. $n$

\section{Registration is open at www.libqual.org
LibQUAL+
(ब)}

\section{Come to the LibQUAL $+{ }^{\circledR}$ Share Fair}

at the 2012 Library Assessment Conference, October 29-31 